\title{
A inespecificidade em 0 pai da menina morta
}

\author{
The non-specific in 0 pai da menina morta
}

\section{La inespecificidad en 0 pai da menina morta}

\author{
iD Tiago Monteiro Velasco \\ Pontifícia Universidade Católica do Rio de Janeiro (PUC-Rio), Rio de Janeiro, RJ, Brasil. \\ E-mail: velasco.tiago@gmail.com
}

\begin{abstract}
Resumo: Este artigo procura fazer uma leitura do romance $O$ pai da menina morta, de Tiago Ferro, a partir de conceitos como literatura inespecífica ou em campo expandido, que vêm sendo discutidos por Florencia Garramuño e Ana Kiffer, e, também, pelo de literatura pósautônoma, de Josefina Ludmer. O artigo discute o uso de fragmentos como construto narrativo nas escritas de si, na representação da memória e na impossibilidade de se narrar a dor. Por fim, procura-se aproximar $O$ pai da menina morta às artes visuais, mais especificamente a obras instalativas.
\end{abstract}

Palavras-chave: Literatura inespecífica. Literatura em campo expandido. Literatura pós-autônoma. Escrita de si. Tiago Ferro.

\begin{abstract}
This article seeks to read the novel $O$ pai da menina morta, by Tiago Ferro, based on concepts such as non-specific literature or in an expanded field, which have been discussed by Florencia Garramuño and Ana Kiffer, and also by post-autonomous literature, by Josefina Ludmer. The article discusses the use of fragments as a narrative construct in writing of the self, the representation of memory, and the impossibility of narrating pain. Finally, it seeks to bring O pai da menina morta closer to the visual arts, more specifically to installation works.
\end{abstract}

Keywords: Non-specific literature. Literature in expanded field. Post-autonomous literature. Writing of the self. Tiago Ferro. 
Resumen: Este artículo busca leer la novela O pai da menina morta, de Tiago Ferro, a partir de conceptos como literatura inespecífica o en campo expandido, que han sido discutidos por Florencia Garramuño y Ana Kiffer, y también por la literatura postautónoma, de Josefina Ludmer. El artículo analiza el uso de los fragmentos como construcción narrativa en la escritura del yo, la representación de la memoria y la imposibilidad de narrar el dolor. Por último, pretende acercar O pai da menina morta a las artes visuales, más concretamente a las obras de instalación.

Palabras clave: Literatura inespecífica. Literatura em campo expandido. Literatura postautónoma. Escritura del yo. Tiago Ferro.

Submetido em 30 de maio de 2021.

Aceito em 20 de agosto de 2021.

Publicado em 17 de novembro de 2021. 


\section{Introdução}

Certas obras da literatura contemporânea parecem querer resistir a qualquer parâmetro razoavelmente estável comum ao sistema literário. Por resistir aos parâmetros que definem a literatura, quer-se dizer não apenas a critérios como personagem, narrador, mas, também, ao gênero do texto, à mídia em que circula e, até, se é ficção ou não, visto que muitas vezes se assemeIham a narrativas jornalísticas, documentais, etnográficas, quando não são textos publicitários, mensagens de WhatsApp, trocas de e-mails. Sem falar, ainda, quando incorporam, por vezes de forma desierarquizada, imagens, fotografias e desenhos. Os exemplos, aqui, não são exaustivos, cumprem apenas a função de ilustrar o aparente vale-tudo nas letras dos dias de hoje - ou, para ser mais preciso, desde pelo menos os anos 1960, embora seja cada vez mais recorrente (GARRAMUÑO, 2014a; 2014b; KIFFER, 2014).

É nesse contexto aparentemente caótico que este artigo discutirá O pai da menina morta, de Tiago Ferro (2018). A autoficção seria a chave de entrada mais óbvia para tratar do livro de Tiago Ferro, mas ela nos parece insatisfatória tanto por encerrar a obra dentro do conceito de autoficção - e de seus limites e imprecisões ${ }^{1}$ - quanto por não dar conta das estratégias contemporâneas empregadas pelo autor, que extrapolam as especificidades do campo literário a partir de dentro da literatura, e que são o objetivo deste artigo.

Para isso, os conceitos de inespecificidade e literatura fora de si, que vêm sendo trabalhados pela pesquisadora argentina Florencia Garramuño (2014a; 2014b) e, também, pela pesquisadora Ana Kiffer (2014), parecem mais pertinentes, bem como o de literatura pós-autônoma, da também argentina Josefina Ludmer (2013). Ready-made, apropriação, colagem, mas não somente, ao serem transpostos do campo das artes visuais para o da literatura, são conceitos também bastante produtivos, como mostra Leonardo

1 Um bom panorama dessa discussão pode ser visto em Ensaios sobre a autoficção, organizado pela pesquisadora Jovita Maria Gerheim Noronha (2014). 
Villa-Forte (2019), para compreender não somente a obra selecionada, mas certo tipo de produção literária contemporânea.

No caso que vamos discutir, o texto desconjuntado, disforme, fora de si joga não apenas com a identidade em trânsito e estilhaçada do narrador que perde uma filha, cuja estabilidade parece apenas existir em função dessa perda/ausência - ele é o Pai da Menina Morta -, mas também com o próprio caos contemporâneo, fragmentário, em que as ideias de realidade e ficção, em meio a um atravessamento incessante e horizontal de imagens, textos e narrativas, estão mutuamente contaminadas, de tal forma que tentativas de se determinar os limites parecem uma maneira imprópria de lidar com obras desse tipo.

\section{Para além da autoficção, uma literatura não específica}

Autoficção é um termo recorrente para se referir a obras da literatura contemporânea. Fundados em um pacto de leitura que é ao mesmo tempo ficcional e autobiográfico, os romances classificados como autoficcionais são escritos por meio de estratégias de embaçamento das categorias de realidade, com passagens e dados no texto que podem ser cotejados com a vida do autor empírico, e de ficção, que, nesse entendimento, seriam as passagens inventadas, criadas pelo autor. Como já comentado, as discussões em torno do que seria a autoficção não são consensuais e partem da problematização da ideia de pacto autobiográfico por meio do qual Philippe Lejeune (2004) define autobiografia.

Apesar de não ter como não associar O pai da menina morta à autoficção, uma vez que o livro se apresenta como romance e, ao mesmo tempo, há uma série de informações, passagens, tanto no texto como no paratexto, que permitem cotejar a história do livro com a vida do autor empírico Tiago Ferro, repisar essa discussão não é o interesse primordial deste artigo. Primeiro, porque toda escrita de si partilha também da ficção. Entendida de uma forma mais ampla do que criação/invenção do autor, ficção, aqui, é uma 
construção, portanto artificial, que joga com a linguagem e que está submetida a regras da narrativa, que envolvem uma temporalidade própria, opções estéticas, ritmo, enfim, uma busca por meio da manipulação da linguagem por determinados efeitos. Segundo, e agora falando de especificidades das escritas de si, a memória não é o lugar do real, mas uma interpretação, no presente, daquele que recorda, sujeita a mudanças de acordo com o momento em que o sujeito lembra, bem como para quais fins essa lembrança vem à tona. A escrita produz uma realidade mais do que se refere a uma realidade externa ao texto. Por mais ancoragem na vida que haja, o tempo da experiência vivida pelo autor não coincide com o tempo da escrita.

O que se está procurando apontar é que a separação entre ficção e escritas autobiográficas, sobretudo quando realizadas em consonância com paradigmas teóricos contemporâneos, não é tão clara e, muitas vezes, é pouco produtiva para analisar determinadas produções², como é o caso de O pai da menina morta.

Dito isso, parece ser importante contextualizar brevemente este "fora de si" e a não especificidade, como a defende Garramuño (2014a; 2014b). O fora de si remete a uma ideia de que algo está fora de um lugar próprio, à parte de uma categoria fechada, única. É o que Rosalind Krauss chamou de campo ampliado ou expandido, em ensaio clássico publicado originalmente no fim dos anos 1970, intitulado A escultura em campo ampliado. Nele, Krauss constata que nos dez anos anteriores muitas obras com pouca ou nenhuma semelhança entre si estavam sendo classificadas como escultura:

corredores estreitos com monitores de TV ao fundo; grandes fotografias documentando caminhadas campestres; espelhos dispostos em ângulos inusitados em quartos comuns; linhas provisórias traçadas no deserto. Parece que nenhuma dessas tentativas, bastante heterogêneas, poderia reivindicar o direito

2 A discussão sobre escritas autobiográficas que problematizam a realidade e a ficção, a memória como produtora de ficções, a instabilidade do sujeito contemporâneo e a impossibilidade de totalização desse eu estão em Discutindo uma autobiografia contemporânea possível (VELASCO, 2016). 
de explicar a categoria escultura. Isto é, a não ser que o conceito dessa categoria possa se tornar infinitamente maleável. (KRAUSS, 2008, p. 129).

Não cabe aqui esmiuçar a discussão de Kraus, que adentra um estruturalismo que não interessa nesta argumentação, mas ressaltar o alargamento de um conceito de modo a dar conta dos fenômenos que estavam acontecendo na arte naquele momento e que, hoje, parecem ser uma das características recorrentes. Tal característica também pode ser observada na literatura contemporânea, ainda que de forma não hegemônica.

Não é à toa que Florencia Garramuño parte da Krauss para pegar emprestado o "campo ampliado" para a literatura e adapta o nome de uma obra de arte visual de Nuno Ramos, Fruto estranho, para nomear seu ensaio Frutos estranhos: sobre a inespecificidade na estética contemporânea. A instalação em questão, do artista visual, escritor e crítico Nuno Ramos, é bastante elucidativa para a compreensão da ideia de inespecificidade (ou campo expandido ou fora de si). A instalação de Nuno Ramos, para Garramuño (2014a),

questiona a especificidade da linguagem artística ao combinar uma série de elementos diversos nos quais se interconectam árvores, música popular, filme e palavra escrita, mas também para nomear o local que parece estar construindo para a arte e para estética uma série cada vez mais importante de textos, instalações, filmes, obras de teatro e práticas artísticas contemporâneas. Frutos estranhos e inesperados, difíceis de ser categorizados e definidos, que, nas suas apostas por meios e formas diversas, misturas e combinações inesperadas, saltos e fragmentos soltos, marcas e desenquadramentos de origem, de gêneros - em todos os sentidos do termo - e disciplinas, parecem compartiIhar um mesmo desconforto em face de qualquer definição específica ou categoria de pertencimento em que instalar-se. ( $p$. 11-12). 
Por último, antes de entrar na obra de Tiago Ferro, é interessante trazer alguns elementos da discussão que a pesquisadora argentina Josefina Ludmer (2013) promoveu em seu ensaio Literaturas pós-autônomas. Ludmer aponta que muitos textos produzidos na América Latina no início do século 21 "atravessam a fronteira da literatura (os parâmetros que definem o que é literatura) e se colocam fora e dentro, como numa posição diaspórica" (p. 128), apesar de serem vendidos em formato de livro, continuarem circulando como literatura e serem incluídos em gêneros literários tradicionais. No entanto, por mais que se apresentem como literatura, não estão sujeitos a uma análise que se utilize de critérios literários, como autor, obra, escrita, estilo.

Não são lidos como literatura porque aplicam à literatura uma drástica operação de esvaziamento; o sentido (ou o autor, ou a escrita) fica sem densidade, sem paradoxo, sem indecidibilidade (ou como diz Tamara Kamenszain, "sem metáfora"), sendo totalmente ocupado pela ambivalência: são e não são literatura, são ficção e realidade. (LUDMER, 2013, p. 128).

Esse tipo de literatura representaria o fim do período autônomo da literatura, um momento em que a cultura e a economia não se distinguem e em que "a realidade (pensada a partir dos meios que a constituíram constantemente) seria ficção e a ficção seria realidade" (p. 129). Esse novo momento, pós-autônomo, segundo Ludmer, implicaria uma nova forma de circulação e recepção do livro e, consequentemente, uma nova forma de ler.

Chama atenção nesse ensaio de Ludmer a ideia de que a literatura está dentro e fora de fronteiras como literatura e não literatura, ficção e realidade. São textos - para tentar não cair na armadilha de uma especificidade literária - que

assumem a forma do testemunho, da autobiografia, da reportagem jornalística, da crônica, do diário pessoal e até mesmo da etnografia em muitos casos com algum "gênero literário" inseri- 
do em seu interior, como, por exemplo, o romance policial ou a ficção científica). Saem da literatura e entram na "realidade" e no cotidiano, na realidade do cotidiano, sendo que o cotidiano é a TV e os meios, os blogs, o e-mail, a internet. Produzem presente com a realidade cotidiana e essa é uma de suas políticas. (2013, p. 129).

É justamente por serem pós-autônomos que não se prestam a uma fixação de gênero dentro da literatura, visto que os gêneros, as escolas literárias e as classificações eram parte de uma disputa pelo poder dentro do campo literário. Sem a especificidade do campo, essas disputas perdem o sentido: sem limites que a definem, não há o que se disputar, não há interior ou exterior, pois não há mais campo (LUDMER, 2013). Por fim:

\begin{abstract}
As literaturas pós-autônomas do presente sairiam da "literatura", atravessariam a fronteira e entrariam em um meio (uma matéria) real-virtual, sem exterior, que é a imaginação pública; em tudo o que se produz e circula e nos invade e é social e privado e público e real. Ou seja, entrariam em um tipo de matéria e um tipo de trabalho social, onde não há "índice de realidade" ou de "ficção", construindo presente. Entrariam na fábrica de realidade, que é a imaginação pública, para narrar algumas histórias cotidianas em alguma ilha urbana latino-americana. A fim de imaginar identidades de sujeitos que se definem fora e dentro de certos territórios. (LUDMER, 2013, p. 133).
\end{abstract}

\title{
Fragmentos do eu e da dor: os silêncios
}

O romance de Tiago Ferro só pode ser chamado de "romance" porque assim foi posto em circulação. Mas, se é romance, é da mesma forma como as esculturas sobre as quais Rosalind Krauss tratou em seu ensaio, um campo expandido do gênero. O pai da menina morta (2018) é construído em um formato fragmentário, 
uma composição estilhaçada, de espelho quebrado em pedaços, que reflete, corta, espeta, deforma, transfigura e cria a história do pai que perdeu a filha de 8 anos de forma súbita, por miocardite decorrente de Influenza B, assim como ocorreu, fora do texto, com o próprio autor empírico Tiago Ferro. O livro parece desconjuntado, sem coesão, lacunar, justapondo e-mails, verbetes de dicionários, listas, memórias, fotografias de acervo pessoal e de acontecimentos históricos, modificados ou não pelo autor, metanarrativa etc.

Escrever em fragmentos parece ser a forma mais precisa para escrever na contemporaneidade, de acordo com o narrador homônimo de Sérgio Sant'Anna no conto $O$ concerto de João Gilberto no Rio de Janeiro, publicado originalmente em 1982:

Estaremos, agora, diante de um novo realismo na literatura brasileira? Um novo realismo que assume uma forma fragmentária? Pois está difícil, hoje em dia, não escrever em fragmentos. Porque a realidade, cada vez mais complexa, também se estiIhaçou. Principalmente para um cara que se desenraizou como eu. Não existe uma cidade que seja a minha cidade. Não existe uma família que seja a minha família. E as minhas vivências, agora aqui no Rio de Janeiro, são cada vez mais diversificadas e fragmentárias em termos de pessoas, lugares etc. (SANT'ANNA, 2014, p. 187-188).

Nessa citação, destaca-se tanto a realidade complexa e estiIhaçada quanto o sujeito desenraizado, sem uma cidade e uma família que podem ser chamadas de suas. Do início dos anos 1980 para a segunda década do século 21, parece que a realidade se tornou ainda mais complexa e estilhaçada, com menos países e cidades para serem chamadas de seus pelos sujeitos em trânsito, cosmopolitas e globalizados, atravessados por imagens e narrativas que pululam, ubíquas, em janelas na internet, sites, livros, jornais, revistas, televisores, pop ups, e-mails, rádios, podcasts, apps de smartphones, redes sociais - em diferentes idiomas, velocida- 
des e restrições de caracteres e em uma temporalidade elástica e sobreposta. Todos, assim, são potencialmente autores, o que reconfigura as categorias de autor e de receptor/leitor. Essa discussão, porém, não nos interessa aprofundar neste artigo. Quer-se apenas chamar atenção para a ideia de que a realidade atual é também construída por textos e imagens de pessoas comuns, muitas vezes mostrando a própria vida ou a versão escolhida da própria vida (automodelização) para as mídias digitais, o que não é tão diferente de uma construção narrativa sobre a própria vida para ser publicada em um livro em forma de romance. Ao menos, no que se refere aos processos artificiais que compõem narrativas - ficções, mesmo que reais.

Para incorporar e dialogar com esse caos estilhaçado, muitos autores têm optado pelos fragmentos em suas obras. Trechos que, apesar de organizados pelo espaço físico da página, parecem não manter uma coesão com o segmento textual anterior nem com o posterior. O pai da menina morta é construído por meio de fragmentos que surgem abaixo de um título entre colchetes que funciona pouco ou nada como chave interpretativa dos fragmentos a que nomeia. Títulos esses que se repetem por diversas vezes ao longo do livro, produzindo um efeito de rotina, repetição, ordinariedade: [eu], [lista], [sábado], [quinta-feira], [cinzas], [hoje], [obituário], [outono], [e-mail] etc.

Os fragmentos também são muito comuns em narrativas que se fiam na memória, portanto frequentes em escritas autobiográficas, sobretudo nas literárias, que preferem incorporar as descontinuidades, falhas, esquecimentos, deturpações e desordens das lembranças, muitas vezes assumindo-as no próprio texto: “Eu não sei com quantos anos fui do berço para a cama, e se naquela época já era comum o uso de grades protetoras, e se eu sempre pedia uma luz acesa até pegar no sono. Não me lembro quando o meu pai deixou de segurar firme a minha mão para eu pular as primeiras ondas do mar." (FERRO, 2018, p. 33).

Se narrar já é uma ficção, porque força uma ordem e uma temporalidade próprias da narração, trazer os fragmentos é uma ten- 
tativa de reproduzir certa desordem, mesmo que essa construção se dê a partir de escolhas do autor para atingir determinado efeito pretendido com a obra. Por mais que qualquer uma das opções - da mais a menos ordenada - busque efeitos de real (BARTHES, 2012), a escolha do fragmento parece querer deixar claro ao leitor o procedimento ficcional ao não criar a ilusão de continuidade existente nas narrativas ordenadas e coesas. Em o Pai da menina morta, não há apenas a descontinuidade entre os fragmentos, mas uma ausência de marcações temporais claras, produzindo um efeito que vai além da não linearidade, mas de uma narrativa produzida em tempo suspenso. Fragmentos cujos títulos poderiam ser indícios de temporalidade, como [quarta-feira], [hoje], [carnaval], [sábado], [domingo.23h42], têm essa função esvaziada tanto na recorrência com que aparecem no livro quanto na falta de uma organização lógica clara que permita ao leitor uma cronologia.

Por fim, os fragmentos, enquanto representação da identidade múltipla, instável, em construção do sujeito contemporâneo ${ }^{3}$, somam-se à especificidade da experiência de vida do autor empírico Tiago Ferro, cuja vivência traumática decorrente da morte da filha foi transfigurada em literatura em 0 pai da menina morta. Ora, se Sérgio Sant'Anna já se sentia desenraizado em 1982, o que quase o obrigava a escrever em fragmentos, como se aproximar, na escrita, do sujeito que em um repente passa de Tiago Ferro a $O$ Pai da Menina Morta, um conjunto de pedaços aleatórios espalhados a esmo?

A opção no romance de Tiago Ferro é materializar no texto esses pedaços aleatórios, em vez de tentar organizá-los em busca de um sentido. O narrador-personagem criado no texto como figura especular, portanto virtual, do Tiago Ferro fora do texto não é minimamente possível de se apreender na totalidade, o que torna infrutífera a tentativa de se conhecer o autor empírico pela obra. Pode-se, no máximo, captar biografemas, mas nunca quem é Tiago

\footnotetext{
3 Stuart Hall, em A identidade cultural na pós-modernidade, chama atenção para a fluidez e instabilidade da identidade em um mundo globalizado, em que há uma compressão do espaço-tempo e um fluxo cada vez mais intenso de trocas globais, de modo que as identidades nacionais se tornam cada vez mais embaçadas. Não apenas, Hall faz um resumo para mostrar como certos paradigmas teóricos acabam por descentrar o sujeito moderno, desestabilizando qualquer ideia de sujeito unívoco, essencial e autoconsciente. $O$ sujeito pós-moderno, então, seria o sujeito descentrado, com identidades em trânsito, eternamente em construção e multifacetadas. Ver mais em Hall (2006).
} 
Ferro, pois ele sabe que não é possível empreender uma narrativa de si estável enquanto sujeito contemporâneo que é e conhecedor dos artifícios da escrita de si. ${ }^{4}$ É nesse contexto, de consciência das impossibilidades e limites da narrativa que vai empreender, que Tiago Ferro inicia o livro com o seguinte fragmento, cujo título é [eu]:

Tenho na clavícula esquerda o que se chama de calo ósseo. Não dá para notar por baixo da roupa. Foi resultado na emenda do osso quebrado em um treino de aikido em janeiro de 1996. Estou com quarenta e um anos e não luto mais. Minha frequência cardíaca só passa de cem batimentos por minuto quando eu faço sexo. Tenho um metro e oitenta e sessenta e quatro quilos. Sem que eu precise praticar qualquer tipo de exercício me apresento em um corpo socialmente aceito. Minha relação com a comida é esta: tanto faz um prato sofisticado ou um sanduíche na esquina. Sempre uso camiseta, jeans e tênis. Sinto pena dos homens elegantes. Como se não bastasse colocar e tirar tantas máscaras sem parar, ainda desperdiçam tempo com o figurino. Prefiro me concentrar no roteiro.

A Minha Filha morreu no dia 26 de abril de 2016. (FERRO, 2018, p. 9).

Como se pode perceber, a descrição desse "eu" é banal. Altura, peso, idade, vestimentas ordinárias, um gosto indiferente por comida. O narrador-personagem, se não pode ser qualquer um, também não oferece ao leitor nada que permita conhecê-lo singularmente. É um tipo comum. Ao fim do primeiro parágrafo, ele dá uma informação que serve como chave interpretativa. Ao dizer que as pessoas colocam e tiram muitas máscaras para viver, assume as identidades múltiplas de cada um, suas performances sociais, encenações da vida real. A escrita de si é mais uma des-

\footnotetext{
40 autor deixa claro o domínio teórico e o conhecimento das questões inerentes às escritas autobiográficas - das mais às menos estilizadas. Isso transparece não só pelos fragmentos metanarrativos, em que reflete sobre o próprio romance, mas pelas citações e intertextos com autores consagrados no gênero, como Marcel Proust, Michel Leiris, Georges Bataille e Karl Ove Knausgård.
} 
sas encenações, tanto do autor no texto quanto do narrador ${ }^{5}$. E, então, ele prefere se concentrar no roteiro. De forma direta, ele anuncia a morte da "Minha Filha", agora um substantivo próprio, personagem da ficção da obra $O$ pai da menina morta.

Mais difícil ainda é narrar a experiência limite da perda de um filho. O Pai da Menina Morta não é um corpo unificado, sólido.

Eu não quero ser O Pai da Menina Morta. Eu sempre serei O Pai da Menina Morta. Não estou procurando ou exigindo qualquer tipo de justiça. Eu simplesmente aceito a dor aguda na ausência. No vazio. Nós também somos feitos de espaços em branco. Nosso corpo não é uma massa densa. É preciso lembrar disso. Há centenas de cavidades, buracos, esconderijos, zonas mortas, terrenos baldios. A medicina nunca procura a dor dilacerante nesses não lugares da massa corpórea. As drogas não agem no vazio. Eu sinto profundamente cada um desses espaços. São abismos internos. (FERRO, 2018, p. 17).

Após o trauma da perda da filha de forma súbita, o pai, estiIhaçado, não tem linguagem para dar conta de tal perda. Dele só é possível falar de forma indireta, por aquilo que as banalidades não dizem sobre o luto, uma dor que não (se) permite narrar e que, por vezes, irrompe no excesso de pragmatismo e objetividade empregados em muitos dos fragmentos da obra. São listas de música, e-mails que dão os pêsames, intertextos que exigem do leitor conhecimentos externos para que se compreenda onde 0 narrador quer chegar; memórias remotas, entre outros pequenos textos narrativos ou não que parecem sempre tangenciar o que se quer falar de fato. Ou seja, é precisamente por não ser escrita que se pode inferir a completa desordem psíquica do narrador, incapaz de elaborar a dor.

As lacunas se materializam no projeto gráfico do romance. São grandes, vazios entre os fragmentos, que, por sua vez, também

5 As escritas (auto)biográficas são mais uma forma, no mundo contemporâneo, de se poder construir subjetividades, assim como as entrevistas, redes sociais etc., naquilo que a argentina Leonor Arfuch (2010) chamou de espaço biográfico. 
são compostos espaços em branco, linhas escritas com poucas palavras, espaços grandes entre uma linha e outra, marcações visuais da ausência. Ou o silêncio, expressão que aparece algumas vezes ao longo do livro, como no fragmento cujo título é [silêncio] e o texto é apenas "Filha?" (FERRO, 2018, p. 21) ou o de título [minhafilha.doc]:

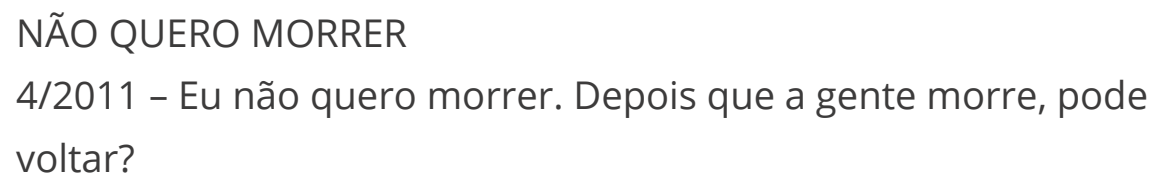

A forma, então, se relaciona diretamente à falta, à incompletude, ao não dito, à ausência de fala, à impossibilidade da narrativa encadeada, do enredo, e mesmo da inexistência de uma explicação para a tragédia.

Novamente, estamos falando de efeito, aquilo que se pretende com as estratégias e escolhas empregadas pelo autor, um artifício que Tiago Ferro (2018) não esconde: "Converso com o F. para publicar um texto sobre o meu processo de luto na revista. Duas pessoas escolhendo em silêncio durante nove semanas de forma obsessiva letra por letra a melhor composição para a dor." (p. 35).

\section{Ready made, colagem, instalação: a literatura e as ar- tes visuais se encontram}

Até aqui discutiu-se a não especificidade de gênero literário característico das escritas de si contemporâneas, em que a autobiografia, em sua vertente poética, e a ficção parecem que não são distinguíveis, ao menos, não categoricamente. Porém, a obra de Tiago Ferro ainda é mais radical no caminho da dissolução de gêneros, tipos textuais e expressões artísticas, na mesma linha de Eles eram muitos cavalos (2013), de Luiz Ruffato, entendido por Flo- 
rência Garramuño (2014a) como uma instalação. Ora, pensar um romance como uma instalação, expressão das artes visuais, sugere que houve uma implosão do próprio meio, embora o formato livro se mantenha.

Para que se entenda melhor o aspecto instalativo de O pai da menina morta, vamos nos deter um pouco na aparência dos fragmentos que compõem o livro, que são também conteúdo do romance. Fora aqueles que se apresentam como o que se entende tradicionalmente por literário - textos memorialísticos, metanarrativas, diálogos, metaficção etc. - há uma série de outros que não são comumente associados à literatura: fotografias, verbetes de dicionários, listas, e-mails, mensagens de WhatsApp, playlists, obituários de jornal, formulários, em suma, expressões de naturezas diversas e, em sua maioria, ordinárias.

Já falamos aqui, citando Josefina Ludmer (2013), como esses textos e imagens do dia a dia estão cada vez mais presentes na literatura de forma desierarquizada, de tal maneira que a realidade entrou na ficção e a ficção constrói a realidade, como se tudo fosse representação e, portanto, não pudesse ser representado. Isso não se dá por acaso, visto que as tecnologias de representação, de produção de imagens e texto, se encontram profundamente difundidas entre a população e são parte constituinte da vida e da identidade de cada um. Dessa forma, o procedimento de escrever sem escrever (VILLA-FORTE, 2019), de copiar e colar, empregado - ou emulado - por Tiago Ferro, é o reconhecimento mesmo das narrativas e discursos entrecruzados que tecem a realidade em que se vive.

Assumir textos e imagens prontos, apesar de alguns serem claramente modificados pelo autor ${ }^{6}$, como os verbetes de dicionário, pode ser entendido como o ready made das artes visuais. O ready made é o deslocamento de um objeto pronto, produzido para um fim não artístico, para uma situação em que é chamado

6 Ao longo do livro, verbetes, e-mails, obituários aparecem com a fisionomia de textos prontos, como se o autor tivesse apenas copiado e colado, mas, em algumas ocasiões, há visivelmente uma alteração no original. Esse procedimento mostra ao leitor que nem tudo que parece é, que a ficção é uma forma de fazer o leitor acreditar na realidade construída no texto. Ao mesmo tempo, por se tratar de uma escrita em que a realidade do autor empírico não pode ser deixada de lado, esse tipo de procedimento opera como forma de desestabilizar a realidade e a ficção, torna o pacto de leitura ambíguo. 
de arte, como o artista francês Marcel Duchamp fez com a obra $A$ Fonte, em 1917, um mictório produzido industrialmente, exposto, em um ambiente legitimado de arte (museu, galeria), de ponta-cabeça e assinado. $O$ trabalho de Duchamp foi o de retirar a função do objeto já existente e transfigurá-lo em obra de arte ${ }^{7}$, da mesma forma que Pierre Menard fez com o Dom Quixote de la Mancha, de Cervantes, no conto "Pierre Menard, autor do Quixote", de Jorge Luis Borges (2001).

Como se sabe, o ready made opera uma série de desestabilizações: a ideia de objeto original, visto que o objeto está pronto e produzido em escala industrial antes mesmo de o artista fazer qualquer tipo de intervenção, o enfraquecimento da técnica e do formalismo como definidores do fazer artístico e mesmo o que se entende por autor. Tudo isso levou à necessidade de se repensar os critérios valorativos e de compreensão sobre a arte, o que também ocorre na literatura em seu momento de pós-autonomia, conforme aponta Josefina Ludmer (2013)

Em O pai da menina morta, Tiago Ferro incorpora ready mades, cria novos textos e os organiza em um espaço físico, o do livro. A isso, Garramuño (2014b) chama de textos-instalações, novamente uma importação para o campo literário de um conceito das artes visuais, a instalação artística, entendida como a organização de ready mades em um espaço físico, criando um ambiente para que a obra seja experimentada de dentro dela.

A fertilização cruzada entre instalação e literatura se materializa na estruturação de um texto composto de fragmentos diversos que se incorporam ao espaço do livro enquanto materialidades heterogêneas. Como se o texto fosse ele também uma instalação, e a sua trama desconjuntada incorporasse objetos diversos no espaço da escrita. (GARRAMUÑO, 2014b, p. 20).

\footnotetext{
7 Com o ready made, Duchamp desvela que o caráter artístico de algo se dá pelo sistema artístico. Ou seja: se o artista afirma que um objeto é arte e o expõe em um museu ou uma galeria, espaços privilegiados da arte, aquele objeto, então, será arte. “Expondo objetos 'prontos', já existentes e em geral utilizados na vida cotidiana, como a bicicleta ou o mictório batizado fontaine [fonte], ele [Duchamp] faz notar que apenas o lugar de exposição torna esses objetos obras de arte. É ele que dá o valor estético de um objeto, por menos estético que seja. É justamente o continente que concede o peso artístico: galeria, salão, museu." (CAUQUELIN, 2005, p. 93-94).
} 
Ora, se esses romances aos quais se refere Garramuño são uma organização de fragmentos, muitos deles retirados diretamente da vida real, fora de contextos literários ou artísticos, os autores, então, se comportam não apenas como criadores, mas, também, como curadores, aqueles que selecionam de arquivos o material que será, por meio do diálogo com outros fragmentos no espaço físico do livro, ressignificado e, portanto, transformado em ficção. Uma organização autoral que dá novo sentido aos fragmentos, visto que a sequência imposta à leitura pelo percurso do livro impresso - da esquerda para direita, de cima para baixo - é algo que os autores levam em consideração na justaposição dos fragmentos. No entanto, em $O$ pai da menina morta, não seria surpreendente se o leitor fizesse um percurso próprio de leitura pelo espaço do livro, lendo os fragmentos de forma aleatória, em uma relação ativa com a construção dos significados a partir da leitura dos objetos-fragmentos, tal qual fariam, analogamente, em uma obra instalativa das artes visuais.

Para se ter uma noção menos abstrata do que se está argumentando a partir da construção proposta por Tiago Ferro, é preciso que se veja, e não apenas se leia. Assim, seguem algumas imagens de fragmentos presentes na obra de modo a tentar dar conta da visualidade, essencial para uma melhor compreensão do que procuro demonstrar, ou seja, que o romance seria uma obra instalativa. A seleção de imagens procura ilustrar, sem exaurir, alguns dos procedimentos de escrever sem escrever, o uso de ready mades, bem como a presença de outras linguagens, em geral estranhas à literatura.

Na Figura 1, vê-se um fragmento cujo título é "[e-mail]" em que o destinatário foi reduzido à função de Pai, com maiúscula. Há uma data que corresponde ao período em que a filha de Tiago Ferro, autor empírico, morreu. Abaixo do cabeçalho, uma mensagem de condolências. 
Figura 1 - Fragmento de título “[e-mail”].

[e-mail ]

RES: Nota de falecimento

De: J. M.W.

Para: Pai

Data: 28/4/20I6 I7h35

Querido,

Se a gente fica com o coração cortado em pedaços só de pensar na morte da sua filha, o que não será em você, com você, de você?

Fonte: O pai da menina morta (2018, p. 15).

Na figura 2, o título do fragmento, "[obituário'], associado ao cabeçalho do jornal Folha de S.Paulo sugere, junto com a data, que houve um obituário da filha de Tiago Ferro no jornal citado. Aqui, então, há uma estratégia de ancoragem no real, índices de texto jornalístico, embora não haja uma narrativa. O fragmento por si só também é elíptico, por mais que a compreensão de seu conteúdo seja clara.

Figura 2 - Fragmento de título “[obituário"]

[ obituário ]

Folha de S.Paulo > Cotidiano > Mortes

Minha Filha (2007-2016)

Menina sempre cheia de colares e pulseiras

ELIANE T.

27/4/2016 23h56

"A criança linda, luminosa ainda ia virar notícia. Boa." 
$\mathrm{Na}$ figura 3, tem-se mais um fragmento não narrativo, em que há a simulação de uma certidão de nascimento em que todos os campos são preenchidos como O Pai da Menina Morta, personagem que nasce a partir da morte da filha, a Menina Morta, de modo que a existência e a subjetividade do narrador se dão em função do acontecimento trágico, na relação entre ele e a filha morta.

Figura 3 - Fragmento de título "[cartório]".

[cartório ]

Nome: O Pai da Menina Morta

Data de nascimento: O Pai da Menina Morta

Estado civil: O Pai da Menina Morta

Sexo: O Pai da Menina Morta

Telefone para contato: O Pai da Menina Morta

Assinatura: O Pai da Menina Morta

Fonte: O pai da menina morta $(2018$, p. 37)

A figura 4 é de uma mensagem de WhatsApp recebida pelo autor no texto, que reproduz uma conversa entre alguém da editora que o publicará, questionando-o sobre os rumos do livro (no momento da mensagem, em processo) que o leitor está lendo.

Figura 4 - Fragmento de título “[whatsapp"]

[whatsapp ]

Oi, querido. O pessoal da editora está um pouco apreensivo. Quantas mortes você ainda pensa em incluir no livro? Acha mesmo que essa mistura de sexo e morte funciona? Não seria melhor encerrar? Beijinho. 
A figura 5 é uma fotografia. O jogador de futebol argentino Maradona domina a bola em jogo da Copa de 1986.

\section{Figura 5 - Fragmento de título “[1986]”}

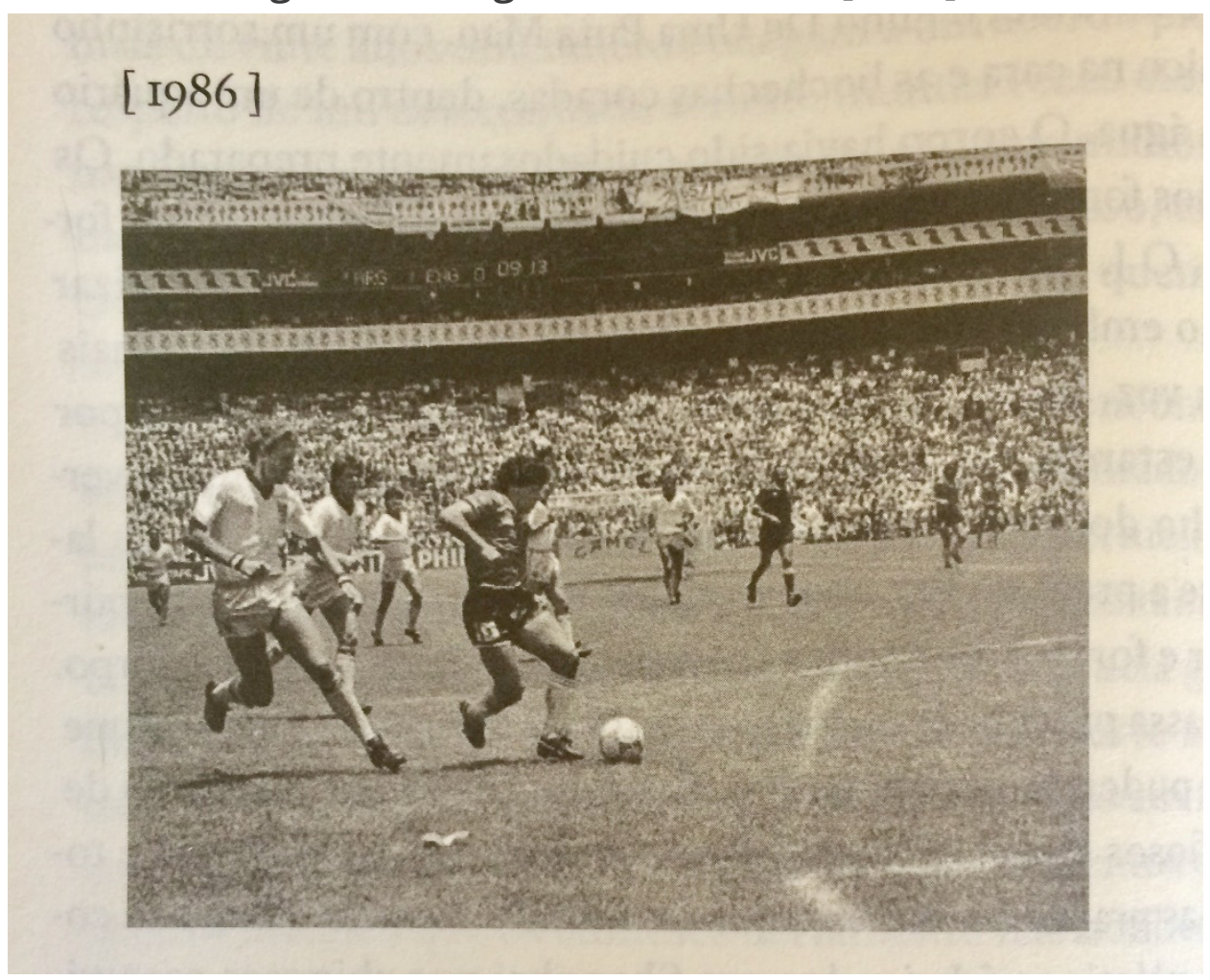

Fonte: O pai da menina morta $(2018$, p. 88).

Para não nos alongarmos ainda mais nos exemplos, a sexta figura é um código em linguagem de programação html, utilizado na construção de sites na internet. O código em questão seria o da construção de um site que se propõe a falar do luto e a ser uma comunidade de pessoas que passam por essa situação. 
Figura 6 - Fragmento de título “[site]"

[ site ]

$<$ html lang="pt-br" ><head $>$

$<$ meta property="og:title" content="Vamos falar sobre 0

luto" $/><$ meta property="og:type" content="article" />

$<$ meta property="og:image" content="http://

vamosfalarsobreoluto.com.br/app/themes/vfsl/dist/images/

share-image.jpg"/><meta property="og:description"

content $=$ "Este projeto é um convite para quebrar o tabu. Um

canal de inspiração e de informação para quem vive o luto e

para quem deseja ajudar." />

Fonte: O pai da menina morta (2018, p. 102).

Diante do exposto, os objetos que compõem essa instalação artístico-literária são os fragmentos - roubados, copiados e colados, rearranjados, remixados, modificados, criados. Uma escrita que não tenta esconder a montagem, que não provoca uma síntese, ao contrário, que deixar ver os elementos em desarmonia e que, dessa maneira, se relaciona à identidade na contemporaneidade: fluida, multifacetada, instável e em eterna construção. E, mais especificamente dentro da obra de Tiago Ferro, o arranjo de fragmentos procura criar uma experiência do ambiente, do espaço de vida, do próprio funcionamento da mente do Pai da Menina Morta.

Assim como nas instalações de arte contemporânea o desenho de um espaço contíguo com o real cava dentro de si um lugar para o espectador, onde ele é confrontado com seu próprio descentramento; a indistinção entre realidade e ficção lança a especificidade da literatura para uma zona em que as elucubrações sobre ela valem mais pelo que dizem com respeito a questões existenciais ou conflitos sociais que habitam esse outro espaço, com o qual se elabora essa contiguidade, do que por aquilo que elas podem dizer a respeito do texto, do texto enquanto tal, em sua especificidade. (GARRAMUÑO, 2014b, p. 21-22). 
Assim, o romance-instalação O pai da menina morta - espaço que é ao mesmo tempo o do livro enquanto mídia e o da mente do Pai da Menina Morta - nos revela tanto pela montagem textual quanto pelos significados de cada um dos fragmentos-objetos, que, neste caso, se apresentam fugidios e desconcertantes, porque optam por dizer sob véus, por meio de intertextos, elipses e mesmo pela opacidade de sentido da coisa comum em um espaço literário, como também acontece em muitas obras minimalistas ou conceituais. Mas, se alguns dos fragmentos podem parecer herméticos em sua banalidade, o leitor se depara com outros mais claros que servem como pontos de apoio para a compreensão das partes entre si e do todo.

\section{Considerações finais}

Na obra de Tiago Ferro, os fragmentos materializam o funcionamento da memória, lacunar, falha, imprecisa, criadora, como a de qualquer escrita do eu. No caso de $O$ pai da menina morta, devido à consciência do autor sobre esse processo, ela também é utilizada de modo a potencializar o aspecto ficcional de toda construção narrativa, em vez de tentar se ater à realidade dos fatos - ou mesmo produzir um efeito tal.

Diante da dificuldade de se narrar a perda de uma filha e o esfacelamento do eu que a tragédia provocou, Tiago Ferro parece ter optado por tentar produzir um efeito no leitor mais próximo da experiência da ausência do que da realidade dos fatos, sem cair em uma autocomiseração. Pelo contrário, a desordem, a objetividade, os ready mades, os vazios, por vezes excessivamente duros, foram as estratégias empregadas para falar daquilo que não é possível.

Desse modo, como na vida, em O pai da menina morta parece não haver espaço para limites rígidos. "Esses fragmentos e essa mescla não perseguem a criação de uma identidade estável, ainda que híbrida. Nessas desinscrições constantes, os elementos hete- 
rogêneos parecem resumir a função da arte a um arquivo desses fragmentos." (GARRAMUÑO, 2014a, p. 23).

Nesse sentido, defendeu-se O pai da menina morta como uma espécie de obra instalativa literária. Isso porque há uma criação de um espaço no livro por meio da organização de fragmentos, ready mades e textos estranhos à literatura, que, no diálogo entre si ativado por um leitor participativo, promove uma experiência estética imersiva e desestabilizadora de uma série de categorias.

Assim, parece claro que essa literatura inespecífica ou em campo expandido não pode ser lida de acordo com critérios tradicionais literários, e por isso o diálogo com as artes visuais contemporâneas tem sido cada vez mais produtivo para se pensar essas obras impertinentes. Conforme defende Ludmer (2013), por fugirem das convenções do literário, esses textos devem ser pensados por meio de critérios que dão conta desse fenômeno, sob o risco de o crítico ou o analista, por utilizar um ferramental inadequado, não conseguir se aproximar dessas obras, de tal forma que poderia, inclusive, considerá-las como não literárias - o mesmo que analisar os ready mades de Duchamp por meio de uma técnica escultórica. E, por serem sem fronteiras definidas e claras, clamam, também, por uma forma inespecífica de crítica e análise.

\section{Referências}

ARFUCH, Leonor. 0 espaço biográfico: dilemas da subjetividade contemporânea. Rio de Janeiro: EdUERJ, 2010.

BARTHES, Roland. O efeito de real. In: BARTHES. 0 rumor da língua. $3^{\text {a }}$ ed., São Paulo: Editora WMF Martins Fontes, 2012, p. 181-190.

BORGES, Jorge Luis. Pierre Menard, autor do Quixote. In: BORGES, Jorge Luis. Ficções. $3^{\mathrm{a}}$ ed., São Paulo: Globo, 2001, p. 53-63.

CAUQUELIN, Anne. Arte contemporânea: uma introdução. São Paulo: Martins, 2005. 
DANTO, Arthur C. A transfiguração do lugar-comum: uma filosofia da arte. São Paulo: Cosac Naify, 2010.

ESCOBAR, Ticio. Identidades en tránsito. Disponível em: http://myslide.es/documents/identidades-en-transito.html. Acesso em: 24 jul. 2016. FERRO, Tiago. O pai da menina morta. São Paulo: Todavia, 2018.

GARRAMUÑO, Florencia. Frutos estranhos: sobre a inespecificidade na estética contemporânea. Rio de Janeiro: Rocco, 2014a.

GARRAMUÑO, Florencia. Formas da impertinência. In: KIFFER, Ana; GARRAMUÑO, Florencia (org.). Expansões contemporâneas: literatura e outras formas. Belo Horizonte: Editora UFMG, 2014b, p. 91-108.

HALL, Stuart. A identidade cultural na pós-modernidade. $11^{\mathrm{a}}$ ed., Rio de Janeiro: DP\&A, 2006.

KIFFER, Ana. A escrita e o fora de si. In: KIFFER, Ana; GARRAMUÑO, Florencia (org.). Expansões contemporâneas: literatura e outras formas. Belo Horizonte: Editora UFMG, 2014, p. 47-68.

KRAUSS, Rosalind. A escultura no campo ampliado. Arte \& Ensaios, Rio de Janeiro, n. 17, p. 128-137, 2008. Disponível em: https://www.ppgav. eba.ufrj.br/wp-content/uploads/2012/01/ae17_Rosalind_Krauss.pdf. Acesso em: 26 set. 2020.

LEJEUNE, Philippe. O pacto autobiográfico. In: NORONHA, Jovita Maria Gerheim (Org.). $\mathbf{O}$ pacto autobiográfico: de Rousseau à Internet. 2 ed., Belo Horizonte: Editora UFMG, 2004, p. 15-55.

LUDMER, Josefina. Literaturas pós-autônomas. In: LUDMER, Josefina.

Aqui América Latina: uma especulação. Belo Horizonte: Editora UFMG, 2013, p. 127-133.

NORONHA, Jovita Maria Gerheim (org.). Ensaios sobre a autoficção. Belo Horizonte: Editora UFMG, 2014.

RUFFATO, Luiz. Eles eram muitos cavalos. $11^{\text {a }}$ ed., São Paulo: Companhia das Letras, 2013.

SANTA'ANNA, Sérgio. O concerto de João Gilberto no Rio de Janeiro. In: SANTA'ANNA, Sérgio. $\mathbf{O}$ concerto de João Gilberto no Rio de Janeiro. São Paulo: Companhia das Letras, 2014, p. 164-211. 
VELASCO, Tiago Monteiro. Discutindo uma autobiografia contemporânea possível. Itinerários, Araraquara, n. 42, p.31-49, jan./jun. 2016. Disponível em: https://periodicos.fclar.unesp.br/itinerarios/article/ view/9693/6380. Acesso em: 28 ago. 2021.

VILLA-FORTE, Leonardo. Escrever sem escrever: literatura e apropriação no século XXI. Rio de Janeiro: Ed. PUC-Rio; Belo Horizonte, MG: Relicário, 2019. 